\title{
ANALYSIS OF CHARACTER EDUCATIONAL VALUES IN FOLKLORE AND THE RELEVANCE IN THE FORMATION OF STUDENT'S CHARACTER IN VOCATIONAL HIGH SCHOOL
}

\author{
I Wayan Agustina', I Made Sutama ${ }^{2}$, I Wayan Rasna ${ }^{3}$ \\ ${ }^{123}$ Language Education Study Program, Program Pascasarjana, Universitas Pendidikan Ganesha, Indonesia
}

\section{Keywords:}

character education, folklore, and literary learning

\section{ABSTRACT}

Abstract: This study aimed to (1) describe the values of character education contained in the folklore that used as subject material in Ganesha Vocational High School and (2) the relevance of the values of character education in the folklore in the development of student character. The design of this research is descriptive-qualitative. The subjects of this study are 10 folklores used in Ganesha Vocational High School and teachers of Indonesian subjects in Ganesha Vocational High School. The object of this study is the values of character education contained in the folklore and its relevance to the formation of student characters. Data collection methods used are documentation and interview method. Data analysis is done descriptivelyqualitative. At the data reduction stage, identification stage is performed, data matching the problem is observed and classified and at the conclusion draw stage. The results showed that from ten folklore stories analyzed there are values of character education as follows; (1) religious (faith, piety, and thanksgiving); (2) responsibility; (3) social concern (public interest, helpers, willing to sacrifice, cooperation, sharing, and loving); (4) honest; (5) curiosity; (6) the spirit of nationality; (7) love the homeland; (8) independent; (9) discipline; (10); love peace; (11) hard work; (12) creative; (13) friendly / communicative; (14) tolerance; (15) appreciate achievement; (16) care about the environment; (17) like to read; (18) democratic. The results of interviews with teachers of Indonesian subjects in Ganesha Vocational High School, folklore contain the values of advice that can be used as teaching materials, so it has relevance for the development of student character. The conclusion of this study shows the value of characters contained in the story of the people of the Indonesian archipelago is very relevant to be a mirror in everyday life.

Correspondance address:

E-mail: ku agustin@yahoo.com (I Wayan Agustina)

\section{Introduction}

The problems that plague the nation are due to our distance from character. The identity of the nation seemed to be uprooted from the real roots. Until education character become a hot topic in talking about. Character building is one of the goals of national education. Article I of the National Education System Act of 2003 states that among the goals of national education is to develop the potential of learners to have intelligence, personality and noble character. According to knowledge constitution in year 2003 that intend for education not only forming human beings intelligent, but also personality or character, so that later will born generation of developing nation with character that breathe noble values of nation and religion. 
Character education is an inseparable part of the learning process. In other words, that character education with the learning process is two things that have a close relationship. That is, the formation of characters can be done through the learning process (Abidin, 2013). In practice can be done by integrating in the learning in school, one of which can be through the subjects of Bahasa Indonesia. In the subjects of Bahasa Indonesia can be done by optimizing the process of learning literature. This is in line with the literary meaning itself that is, the literature is beautiful and as well as a medium or tool to educate. Literature is not just something that can provide beauty or entertainment, but it can also benefit.

According to Wibowo (2013: 129) by appreciating literary works such as, short stories, novels, folklore, and poetry can form good characters in students. One of the literary works mentioned by Wibowo is folklore. Folklore is a form of oral literature containing good values. Thus, there is no harm if the folklore used as one of the materials in the process of character education. Folklore is a form of oral literature. Oral literature in the form of folklore is one reflection of a society. This is because literature has a very important role and also a regional culture. The advancement of national culture is of course very much related to the regional culture, including the oral literature (folklore). One form of preservation and development of oral literature, especially folklore is to make it as a material in learning literature in school. However, what must be considered in this case is to adjust the material folklore with the existing curriculum of learning. The form of adjustment is to see the relevance of the story with the existing material in the literature that the scope is on the subjects of Bahasa in school. In other words, that the folklore can not necessarily be directly used as learning materials, but it should be seen whether the folklore is relevant or not based on the predefined learning curriculum.

Based on the above, very important folklore is used as an alternative in the learning of literature, whose scope is on the subjects of Bahasa. The character formation of students in vocational high school is needed to reduce and prevent students to do bad things such as: the number of cases of students who brawl, the number of students who are not ready (mental) face National exam, the existence of drug addict students, and this all shows the negative character of students. All these negative characters can be eliminated or reduced through the formation of student characters. All ways have been done by the government to eliminate the negative public opinion about vocational students who like to do brawl and others as mentioned above. Though it is all the influence or negative impact of association, which is where this formation of character education is needed.

This phenomenon encourages researchers to examine the values contained in the folklore used as a teaching material by teachers in Ganesha Vocational High School. Through this research the researcher wants to show that every region in Indonesia has a variety of folklore that can be used as relevance in the development of student character in vocational high school. The results of interviews with teachers that the character of vocational high school students still need to be improved. Through a deep understanding of folklore, learners and educators become easier in instilling character education through characters in the story. This is the reason the authors analyze the text in the folklore with the assumption that by conducting an analysis of the aspects of characterization and mandate, we can know the values of education of any character contained in the folklore and its relevance in the formation of characters poured the narrator through figures in the folklore.

\section{Research Methods}

This research uses qualitative descriptive method. This study focuses on the character values contained in folklore. This study was conducted with the aim to describe the values contained in folklore in the formation of character and its relevance. The subjects of this study are two; the first is a collection of folklore textbook used in Ganesha vocational high school. The author selecting Ganesha vocational high school as research place because students of vocational high school have a 
high imagination is considered worthy of its character formation is done through folklore. The reason for the selection of subjects of folklore 1) Batu Menangis, 2) Dewi Nawangwulan, 3) Anak-Anak Yang Hilang, 4) Malin Kundang, 5) Panji Semirang, 6) Asal Usul Surabaya, 7) Dewi Sanggalangit, 8) Asal Mula Selat Bali, 9) Raja Yang Culas, dan 10) Sangkuriang because of similar folklore that existence is increasingly faded and received less attention from the public. The folklore that exist in Indonesia is very important to be preserved. This is done because in the midst of incessant globalization and foreign influence through the world of literature and entertainment impacts the threat of the destruction of folklore filled with the content of values (Putra, 2011). The choice of folklore is also on the grounds that the folklore is very rich with values that are useful in life (Rampan, 2014: 13). Thus the folklore is worthy of study to obtain a definite clarity about the values of character education contained in each folklore. While the second research subject is Indonesian language teachers. Objects studied in this study is the value of character education values contained in folklore used in vocational high school and its relevance to the formation of student characters.

Methods of data collection in this study are the method of documentation and interview. This documentation method is done to avoid forgotten data due to the limited memory of the author. Documentation is the main method in this research. The folklore to be analyzed is collected and then reviewed according to the formulation of the problem and recorded the results in the data card, to collect the data, and then needed an instrument. The tools used to record the data in the study are interview guides and documentation results. Interview guides contain informant questions. Documentation includes a record of the folklore used in Ganesha vocational high school and the condition of student character. The data is about the value and character education contained in the text of folklore used in Ganesha vocational high school.

In this study is used qualitative descriptive analysis. Data analysis is done since before entering the field, during in field, and after finished in field. But in qualitative research, data analysis is more focused during the process in the field along with data collection. Once the data is collected as a whole, and then the data are classified, described, and analyzed based on the research problem. In detail the data analysis techniques are as follows:

1) Read critically and deeply the folklore contained in the book collection of folklore archipelago.

2) Analyze the value of characters in folklore based on the indicator of the value of the characters that have been provided.

3) Write proof of character value into the character value table.

Miles and Huberman in Sugiyono (2015) argued that the activity in qualitative data analysis is done interactively and continuously until complete, so the data is saturated. The data collected through the documentation method will be analyzed through three stages: data reduction, data presentation, to the inference stage. In this study the researchers read critically and deeply the collection of folklore contained in the book collection of folklore. Furthermore, the researcher selects the main points that can be analyzed and dispose of data that are considered unimportant. Data reduction is done through activities in the form of identification and classification. Data that has been reduced will be presented next data description which will be described in detail and clear. In the presentation of data, the data obtained will be associated with relevant theories that will be able to answer the problems to be solved. In this study the descriptions are done on each data in accordance with the presentation of data. The inference must be able to answer all the issues that will be raised in the research, so that the final result will be obtained information about the values of character education in folklore and its relevance in the formation of student character in school.

\section{Result and Discussion}

Based on analyzed the aspects of characterization and mandate, the writer can know the values of character education contained in the folklore and its relevance in the formation of student character. The value of educating the character, namely: (1) religious (faith, piety, and thanksgiving); 
(2) responsibility; (3) social concern (public interest, helpers, willing to sacrifice, cooperation, sharing, and loving); (4) honest; (5) curiosity; (6) the spirit of nationality; (7) love the homeland; (8) independent; (9) discipline; (10); love peace; (11) hard work; (12) creative; (13) friendly / communicative; (14) tolerance; (15) appreciate achievement; (16) care about the environment; (17) like to read; (18) democratic. The value of character education is the value of character education contained from all existing stories. The value of character education found in this study was then classified by three categories. The three categories are (1) the value of character education related to oneself; (2) the value of character education related to other people / creatures; and (3) the value of character education related to divinity.

Character education is an inseparable part of the learning process. In other words, that character education with the learning process is two things that have a close relationship. That is, the formation of character can be done through the learning process (Abidin, 2013). In a learning process there are learning materials that will be taught to students. Learning materials that will be taught to the students must have been adapted to the subjects, curriculum, and level of student education to be taught. The learning materials are planned before the implementation of the learning process. A material on each subject can be poured into the teaching materials. So is the Indonesian language. Teaching materials on Indonesian subjects contain many moral values that can be used as a means of delivering the values of character education. The teaching materials in question are teaching materials in the form of literary works. Abidin (2013) argued that the teaching material in the form of literature is the most appropriate teaching materials used as a channel of character education. He argues that literary works have values that can be used to shape student manners. Through literary works, students can find good characters to emulate and apply in everyday life, whether in family, school, or society. Character education values such as; honesty, kindness, friendship, brotherhood, kinship, sincerity, togetherness, and other character values.

Through character education contained in the folklore is expected vocational high school learners are able to independently improve and use their knowledge, review and internalize and personalize the values of character and noble character so that embodied in everyday behavior. According to teacher, the folklore contains the values of advice that can be used as teaching materials, so it has relevance as a literary learning material in shaping the character of students. This is due to the suitability between the existing story and criteria of literary learning materials, especially in class $X$. Based on the analysis of the value of character education contained in it, each folktale in this study has many positive character values, but there is also a negative value. The folklore that contains many positive character education values can be used as an example and a negative to be abandoned, so that the folklore allows to be used as a literary learning material in shaping the character of the students.

Desi Bidrawati argues that character education in folklore can be integrated into the learning of literature in Indonesian subjects for high school / vocational school level. Then, the content of the values contained in the folklore of the archipelago is also a manifestation of contextual learning and the important character taught to students. Seen from Curriculum 13 (K-13), literary material about folklore is taught in class $\mathrm{X}$ semester one. The core competencies concerning attitude, both spiritual attitudes (KI: 1 ) and social attitudes ( $\mathrm{KI}: 2$ ) are related to the linguistic concept of values, cultural norms, and social context that form the basis of character formation; the core competencies concerning knowledge (KI: 3 ) and skill (KI: 4$)$ are directly related to the linguistic concept associated with the social process (genre). In addition, the basic competencies (KD) grouped under the main competency have a fundamental relationship with each other. The achievement of basic competency in the main competency group: 1 and 2 is determined by the achievement of basic competency in the main competency group: 3 and 4 .

Character education in schools is also closely related to school management or management. The management in question is how character education is planned, implemented, and controlled in educational activities in schools adequately. The management includes, among other things, values that need to be inculcated, curriculum content, learning, assessment, educators and education personnel, and other related components. Character education target is all Vocational High School 
(SMK) in Indonesia both public and private. All school residents, including students, teachers, administrative staff, and school leaders are targeted by the program. Schools that have been successful in carrying out character education as well as best practices, which became an example to be disseminated to other schools. Through this program is expected vocational high school graduates have faith and devotion to God Almighty, noble character, full and integrated academic competence, as well as having a good personality according to the norms and culture of Indonesia. On a wider level, character education is expected to become a school culture. The success of the character education program can be known through the achievement of indicators by learners as stated in the Competency Standards of vocational high school Graduates.

The character formation of students in vocational high school is needed to reduce and prevent students to do bad things such as: the number of cases of students who brawl, the number of students who are not ready (mental) face National exam, the existence of drug addict's students, this all shows the negative character of students. All these negative characters can be eliminated or reduced through the formation of student characters. All the way the government has done to eliminate the negative public opinion about vocational students who like to do brawl and others as mentioned above. Though it is all the influence or negative impact of association, which is where this formation of character education is needed.

\section{Conclusion}

Based on the problem proposed, the result of the study on the analysis of educational values in Nusantara folklore and its relevance in the development of student character can be summarized ten stories of the people of the archipelago used in Ganesha vocational high school are analyzed descriptively qualitative there is the value of character education in this study taken from the character of the characters in the story of a good (positive). The value of educating the character, namely: (1) religious (faith, piety, and gratitude); (2) responsibility; (3) social concern (public interest, helpers, willing to sacrifice, cooperation, sharing, and loving); (4) honest; (5) curiosity; (6) the spirit of nationality; (7) love the homeland; (8) independent; (9) discipline; (10); love peace; (11) hard work; (12) creative; (13) friendly / communicative; (14) tolerance; (15) appreciate achievement; (16) care about the environment. The value of character education is the value of character education contained from all existing stories.

The folklore contains the values of advice that can be used as teaching materials, so it has relevance as a literary learning material in shaping the character of students. This is due to the suitability between the existing story and criteria of literary learning materials, especially in class X. Through this character education development program is expected Ganesha vocational high school graduates in particular have faith and devotion to God Almighty, noble character, and noble character, full and integrated academic competence, as well as having a good personality according to the norms and culture of Indonesia. On a wider level, character education is expected to become a school culture.

\section{References}

Abidin, Y. (2013). Pembelajaran Bahasa Berbasis Pendidikan Karakter. Bandung: PT Refika Aditama. Putra, I. N. D. (2011). Politik Identitas Dalam Teks Sastrawan Bali. Jurnal Kajian Bali, 1(1), 124-151. Sugiyono. (2015). Metode Penelitian Pendidikan. Bandung: Alfabeta. 